\title{
CONTRIBUTIONS TO A CATALOGUE OF ALIEN PLANTS IN TASMANIA III
}

\author{
by Matthew L. Baker \\ (with four text-figures and three plates)
}

\begin{abstract}
Baker, M. L. 2011(9:xii): Contributions to a catalogue of alien plants in Tasmania III. Papers and Proceedings of the Royal Society of Tasmania 145: 27-34. https://doi.org/10.26749/rstpp.145.27 ISSN 0080-4703. Tasmanian Herbarium, Tasmanian Museum and Art Gallery, Private Bag 4, Hobart, Tasmania 7001, Australia. Email: Matthew.Baker@tmag.tas.gov.au
\end{abstract}

The status of six alien plant taxa recorded in Tasmania is discussed. Cordyline australis (G.Forst.) Endl., Lupinus $\mathbf{X}$ regalis Bergmans, Pittosporum crassifolium Banks \& Sol. ex A.Cunn., Pittosporum eugenioides A.Cunn., Pittosporum tenuifolium Gaertn. and Pittosporum undulatum Vent. are ornamental taxa that are now recognised as naturalised in Tasmania. A description for each taxon is provided and distribution and habitat details are discussed. Keys to the Tasmanian species of Lupinus L. and Pittosporum Banks ex Gaertn. are included.

Key Words: naturalised, exotic, weeds, introduced, flora, Pittosporum, Cordyline, Lupinus.

\section{INTRODUCTION}

Management of Tasmania's alien flora requires an accurate and up-to-date account of taxa present. This paper is the third of a series (Baker 2005, 2007) which aims to ensure that taxa that become naturalised in Tasmania are formally recorded; that taxa that are present in Tasmania, but have not become fully naturalised ["sparingly naturalized" in the sense of Buchanan (2005) and Baker (2005)] are likewise recorded; that new incursions of alien taxa are recorded; and to maintain up-to-date names for taxa that have been affected by nomenclatural change. In this paper, six taxa are treated, giving diagnostic descriptions and notes on their distribution. It is hoped that this information will increase general knowledge of distribution of naturalised alien taxa in Tasmania and raise community awareness of plants that have the potential to become naturalised.

Reports of new incursions, naturalised and sparingly naturalised species are welcomed by the author. Specimens and relevant collection information can be forwarded to the Tasmanian Herbarium.

\section{MATERIALS AND METHODS}

Primary sources used for this study are specimens held in the Tasmanian Herbarium (HO). Herbarium abbreviations follow Holmgren et al. (1990). Identifications by the author and others were checked against literature and, where available, reliably identified voucher specimens.

Voucher specimens for all species treated have been lodged in the Tasmanian Herbarium. The naturalised status of treated species is based upon field observations made by the author and others and, when available, from notes accompanying specimens.

The placement of genera in families follows the Flora of Tasmania Online (Duretto 2009).

Citations of synonyms are limited to names used in Tasmanian literature. Tasmanian distributions follow floristic regions proposed by Orchard (1988). Geographical origins of plants treated have been determined from various published sources. Definitions of "alien" and "naturalised" and "sparingly naturalised" have been discussed by Baker (2005).

\section{NATURALISED TAXA IN TASMANIA}

\section{Cordyline australis (G.Forst.) Endl., Prodr.} fl. Norfolk.: 29 (1833). (Laxmaniaceae)

Common name: New Zealand Cabbage Tree

Illustrations: Richardson et al. (2006: 8); Conran \& Walsh (1994: 719); Spencer (2005: 302, pl. 8); pl. 1.

Description: Tree to $12(-20) \mathrm{m}$ tall. Stems $5-10 \mathrm{~cm}$ diam. in young, unbranched plants, increasing to $150 \mathrm{~cm}$ diam. in branched, mature plants (massive trunks not seen

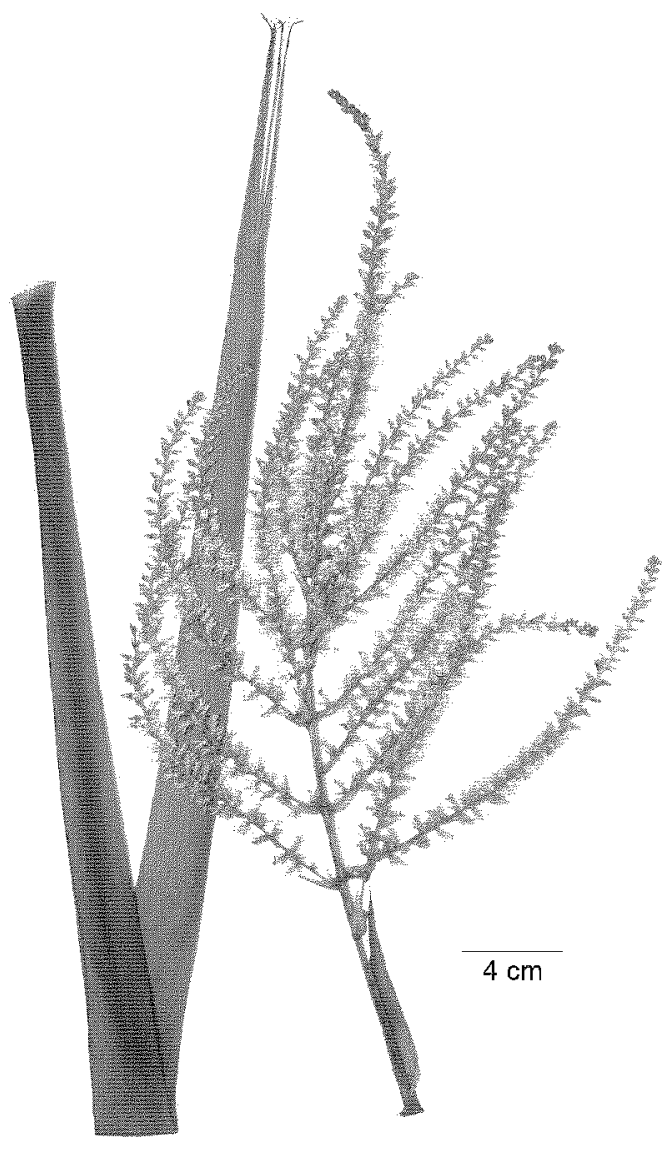

PLATE 1

Leaf and inflorescence of Cordyline australis. 
in Tasmania to date). Bark rough, fissured. Leaves spirally arranged, clustered at the ends of branches, erect at first, becoming spreading and then deflexed at maturity, senescent leaves often remaining on the trunk; lamina narrow-linear, up to $100 \mathrm{~cm}$ long, $3-6 \mathrm{~cm}$ wide, light green with many fibrous, parallel veins; base wider than proximal half of lamina and \pm stem-clasping; margin entire; apex acute, often fraying when mature. Inflorescence a large, bracteate, many flowered terminal panicle to $150 \mathrm{~cm}$ long. Flowers subtended by 2 dimorphic bracts; pedicels to c. $1 \mathrm{~mm}$ long; tepals 6, white, 5-6 mm long, free almost to the base, spreading; stamens 6 , tequal to tepals; ovary superior, globose; stigma trifid. Fruit a globose capsule, c. $4 \mathrm{~mm}$ diam., whitish. Seeds c. $2.5 \mathrm{~mm}$ long, glossy, notched on one side.

Other descriptions can be found in Moore \& Edgar (1970) and Conran \& Walsh (1994).

Discussion: Cordyline Comm. ex R.Br. is a genus of about 20 species. The majority is endemic to Australia and New Zealand with others restricted to southeast Asia, India, New Guinea, New Caledonia, South America and the Mascarenes (Conran 1998). Nine species are native to mainland Australia and one further species, C. australis, is naturalised. Several species, including C. australis, C. fruticosa (L.) A.Chev. and C. stricta (Sims) Endl. are cultivated for their "architectural" foliage (Spencer 2005). C. australis is immediately recognisable by its long, strap-like leaves, tree-like habit and non-serrated leaves.

Distribution and babitat: Cordyline australis is endemic to New Zealand where it grows in a range of generally open habitats, including forest margins, exposed hillsides, sea cliffs and close to swamps (Moore \& Edgar 1970, Simpson 2000). It occurs on both the North and South Islands and on Stewart Island (Moore \& Edgar 1970). In

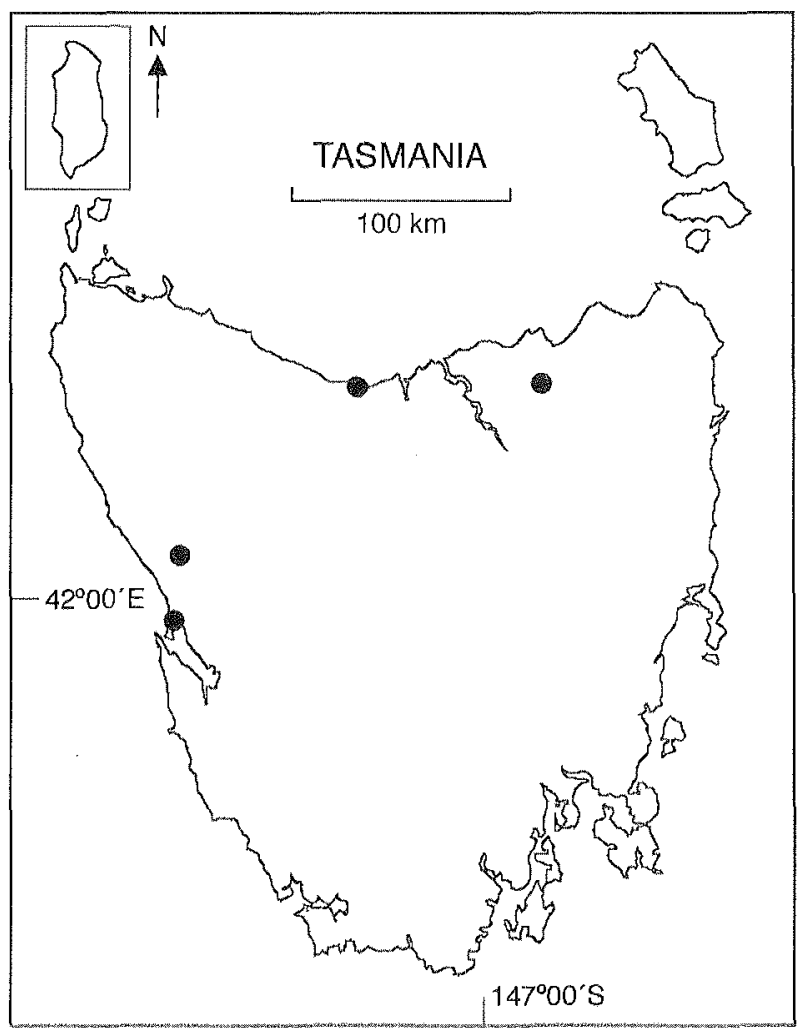

FIG. 1 - Geographical distribution of Cordyline australis as known from herbarium specimens.
Australia, it is naturalised in South Australia, Victoria and Tasmania. In New South Wales, it has only been recorded as sparingly naturalised in the Blue Mountains area of the Central Tablelands (Wilson 2011). In Victoria, it is naturalised in rainforest near Mallacoota in the far east of the state (Conran \& Walsh 1994). In Tasmania, it is widely naruralised across the state (fig. 1), much more widely than herbarium specimens indicate. Notable occurrences have been observed in and around the town of Zeehan on the West Coast, and a particularly large population (approx. 50 plants) grows in Phragmites australis (Cav.) Trin. ex Steud. wetland on the Tamar River.

First record: 1986, D.I. Morris.

Selected specimens examined: TASMANIA: West Coast region: Strahan, 23 Nov. 1998, A.M. Buchanan 15345 (HO); Zeehan Highway, 200 m east of Little Henty River, 15 Sep. 2004, M.L. Baker 592 fr A.M Gray (HO). North West region: Don Heads, 17 Nov. 1986, D.I. Morris 8669 (IO, CHR, CANB, NSW). North East region: Little Forester River, 11 Feb. 2009, M.L. Baker 1956 (HO). VICTORIA: Wallagaraugh River, $1 \mathrm{~km}$ downstream from Gipsy Point settlement, 21 Oct. 1991, N.G. Walsh 3139 (HO, MEL, BRI, CANB, CHR). NEW ZEALAND: Napier, Puketitiri Road, 15 Jun. 1984, A.M. Buchanan 3661 (HO); Norrh Auckland, Bay of Islands, $3 \mathrm{~km}$ from Pahia, 15 Jan. 1986, J. Glasson 97 M.A. Bloomfield (HO, CHR); Manuka Bay, Port Robinson, 25 Feb. 1993, A.M. Buchanan 13182 (HO).

\section{Lupinus $x$ regalis Bergmans, Vaste $\mathrm{Pl}$. Rotsheesters: 328 (1924). (= L. arboreus Sims $x$ L. polyphyllus Lindl.) (Fabaceae)}

Common name: Russell Lupin

Illustrations: Richardson et al. (2006: 263) as Lupinus polyphyllus; pl. 2.

Description: Erect perennial herb to $1.5 \mathrm{~m}$ tall. Stems sparsely sericeous. Leaves alternate, palmately compound, with 5-14 leaflets; petiole up to $170 \mathrm{~mm}$ long, with leaflets elliptic to oblanceolate, $30-95 \mathrm{~mm}$ long, $10-20 \mathrm{~mm}$ wide; adaxial surface glabrous; abaxial surface sericeous; base attenuate; margin ciliolate; apex acute to apiculate; stipules narrow lanceolate to narrow triangular, $5-12 \mathrm{~mm}$ long, up to $2 \mathrm{~mm}$ wide. Inflorescence a many-flowered, terminal raceme to $600 \mathrm{~mm}$ long; peduncle up to $140 \mathrm{~mm}$ long. Flowers arranged spirally to whorl-like; pedicels up to $10 \mathrm{~mm}$ long in fruit; calyx 5-6 mm long, densely sericeous, with upper lip shallowly 2-toothed and lower lip slightly longer and entire; corolla various shades of blue, pink, purple, yellow and white, sometimes two-toned, up to $15 \mathrm{~mm}$ long. Fruit an oblong, 2-valved pod, 28-40 $\mathrm{mm}$ long, up to $8 \mathrm{~mm}$ wide, densely villous, containing up to 10 seeds, style persistent in fruit. Seeds ellipsoid, slightly laterally compressed, 2-4.5 $\mathrm{mm}$ long, 2-2.8 mm wide, mottled brown.

Other descriptions can be found in Webb (1988) as Lupinus polyphyllus and Stace (2010).

Discussion: Lupinus L. is a genus of about 200-220 species (Spencer 2002, Mabberley 2008). It is native in North America, extending south along the Andes, with a few mainly annual species in southern Europe, tropical African highlands and southwest Asia (Phillips \& Rix 2002, Mabberley 2008). Seven species are naturalised in Australia. In Tasmania, two taxa, $L$. arboreus and $L . \times$ regalis, are naturalised; $L$. angustifolius $\mathrm{L}$. is regarded as sparingly naturalised as it is known only from a few small roadside populations in the north of the state. Several species are cultivated in Australia 


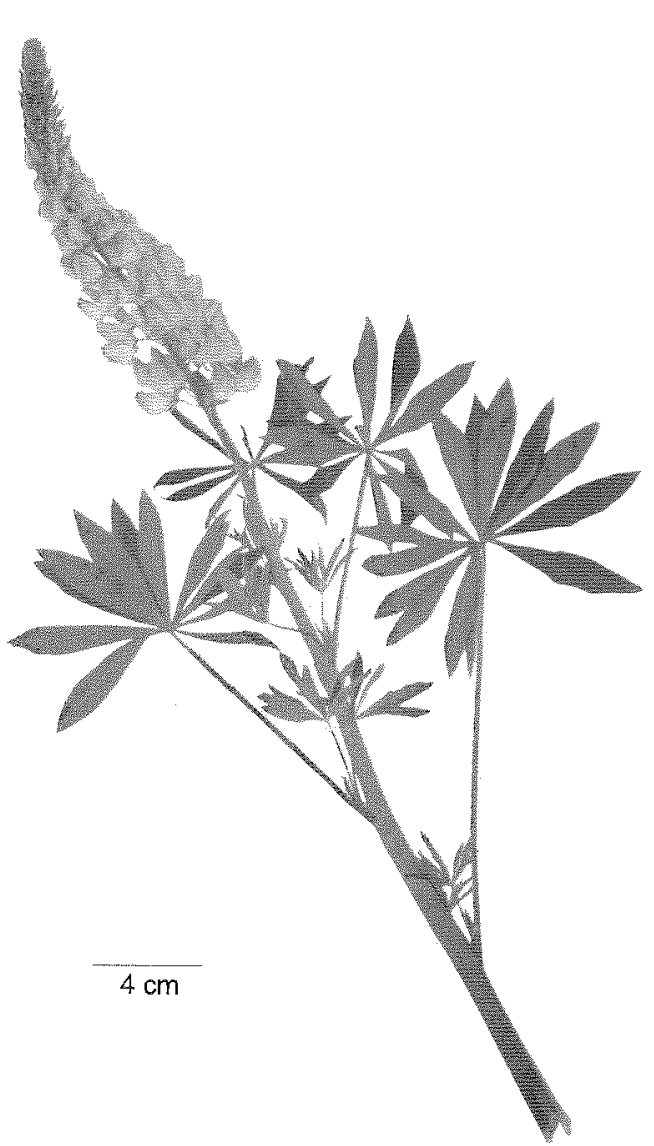

PLATE 2

Flowering branch of Lupinus $X$ regalis.

as garden ornamentals, green manure crops and as broad acre crops. Lupinus albus L. (Albus Lupins, Broad Leaf Lupin, Lupini Beans) and L. angustifolius (Narrow Leaf Lupin) are grown in Tasmania as grain legumes for both animal feed and for human consumption (Knox et al. 2006).

Lupinus $\mathrm{X}$ regalis can be readily distinguished from other Tasmanian lupins by the large showy inflorescences that exhibit a range of corolla colours within a single population. This is in contrast to yellow in $L$. arboreus and blue in $L$. angustifolius. Plants growing at Storys Creek have flowers that are mainly whitish in colour but plants with pink and purple flowers are also present. Blue and white flowered forms are most commonly encountered in naturalised plants in New Zealand (Webb 1988).

\section{Key to the species of Lupinus in Tasmania}

1. Annual herb; corolla blue .......... L. angustifolius

1: Perennial herb or woody shrub; corolla yellow or of various colours including pink, blue and white ......2

2. Woody shrub, usually growing in sandy coastal sites; corolla yellow........................... L. arboreus

2: Perennial herb, usually growing in cool highland areas; corolla of various colours, usually pink, blue or white L. $\mathrm{x}$ regalis

Distribution and habitat: Lupinus $\mathrm{x}$ regalis is a garden hybrid (or hybrid complex) with the parents being $L$. polyphyllus and L. arboreus (both native to North America), and possibly involving some annual species (Huxley 1999, Spencer 2002). In New Zealand, it grows in riverbeds

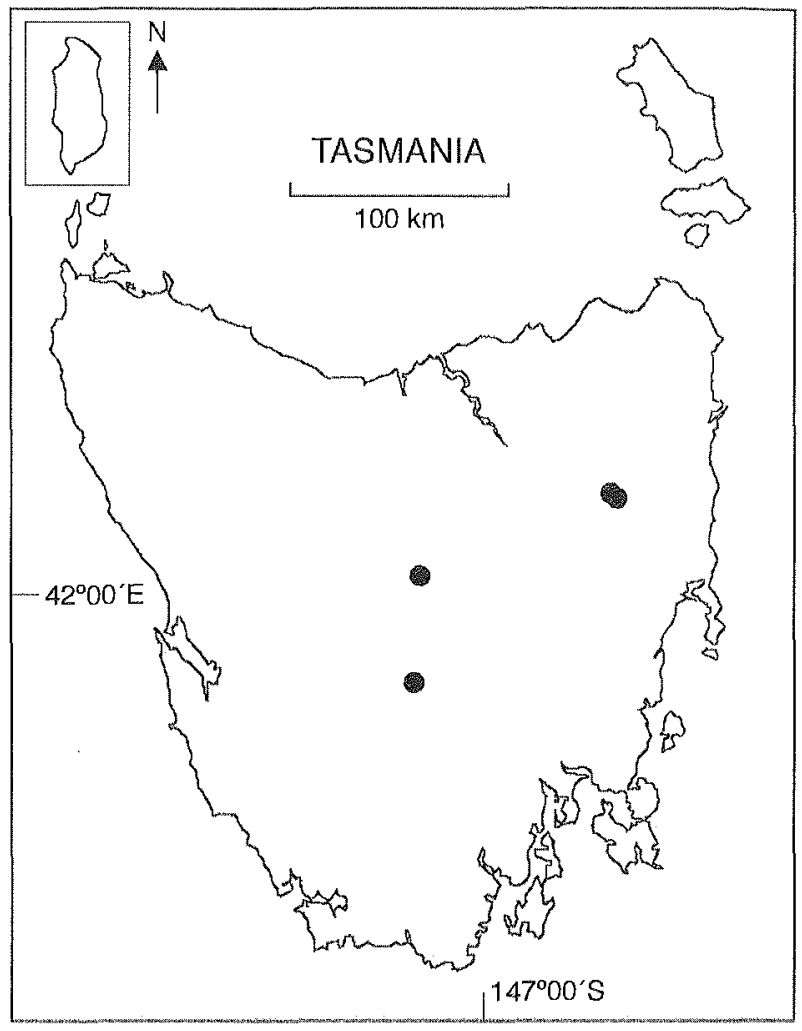

FIG. 2 - Geographical distribution of Lupinus $\mathrm{X}$ regalis as known from herbarium specimens.

and waste places, established locally in lowland areas, but is widespread in streams and riverbeds in montane to subalpine areas (Webb 1988). It is particularly invasive and troublesome in the braided riverbeds in the Canterbury region (Anon. 2007). In Australia, one of the parents, $L$. polyphyllus, is naturalised in New South Wales (Gardner \& Murray 2002) and Victoria (Walsh \& Stajsic 2007) and "questionably established" in South Australia (Barker et al. 2005). Images for the Lupinus polyphyllus entry in PlantNET (The Royal Botanic Gardens and Domain Trust 2011) and the common name used in Gardner \& Murray (2002) suggest that naturalisations under L. polyphyllus in New South Wales are referable to $L . \mathrm{x}$ regalis. Examination of material held in mainland herbaria would be needed to determine the identity of all specimens currently being called L. polyphyllus. The same may be true in Australia, as it is in the British Isles and New Zealand that L. polyphyllus is rarely encountered and most records under that name are in fact L. $\times$ regalis (Webb 1988, Stace 2010). In Tasmania, L. $\mathrm{X}$ regalis has been recorded fiom a small number of locations where it has most likely persisted and spread from abandoned gardens (fig. 2).

First record: 1999, A.M. Buchanan.

Specimens examined: TASMANIA: Central Highlands region: Miena, 1 Dec. 1999, A.M. Buchanan 15592 (HO). East Coast region: Lyell Highway, just $\mathrm{N}$ of turn-off to Strickland, 21 Nov. 2005, M.L. Baker 1663 er A.M. Gray (HO). Ben Lomond region: Storys Creek township, 22 Feb. 2006, M. Wapstra, R. Dillon \& D. Rathbone s.n. (HO); Rossarden Tip, 21 Nov. 2007, M.L. Baker 1839 (HO); Storys Creek, 21 Nov, 2007, M.L. Baker 1836 (HO, MEL, CANB). 


\section{Pittosporum Banks ex Gaertn., Fruct. Sem. Pl. 1: 286, t. 59, fig. 7 (1788).} (Pittosporaceae)

Description: Trees or shrubs. Leaves simple, alternate, entire, petiolate, exstipulate. Inflorescence terminal or axillary; flowers solitary or in many flowered cymes; sepals 5; petals 5; stamens 5; pistil 1, ovary superior, carpels 2-5. Fruit a loculicidal capsule; seeds few to many, immersed in viscous fluid.

For a comprehensive description of Pittosponum in Australia see Cayzer et al. 2000.

Discussion: Pittosporum is a genus of about 100-200 species (Cayzer et al. 2000, Mabberley 2008) native to Australia, New Zealand, Malasia, the Pacific Islands, eastern Asia north to Japan, India, Sri Lanka and westwards to Africa. In Australia, 20 species are native and a further five species and one hybrid (P. bicolor Hook. X P. undulatum) are naturalised. Several New Zealand species are commonly grown as garden plants in Australia (e.g., P. tenuifolium and $P$. engenioides) and it is such species that are the source of naturalised taxa, especially as their seeds are consumed and spread by birds. Observations have been made of Blackbirds (Turdus merula L. 1758) consuming seeds of P. undulatum (Cooper 1959). In Tasmania, one species is native $(P$. bicolor) and four species ( $P$. crassifolium, $P$. eugenioides, $P$. tenuifolium and $P$. undulatum) and one hybrid ( $P$. bicolor $\times P$ undulatum) are naturalised. A key to all Tasmanian taxa and treatments of the four naturalised species is given below.

\section{Key to the species of Pittosporum in Tasmania}

1. Leaves without a prominent yellow midrib; fruit more than $6.5 \mathrm{~mm}$ long ......

1: Leaves with prominent yellow midrib; fruit less than 6.5

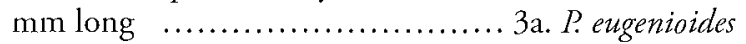

2. Fruit opening by three valves; petals maroon ......... 3

2: Fruit opening by two valves; petals yellow with maroon markings or cream.....

3. Abaxial leaf surface persistently tomentose; flowers several in terminal umbels..................3c. P. crassifolium

3: Abaxial leaf surface glabrous; flowers usually solitary in leaf axils...................... 3b. P. tenuifolium

4. Leaves $6-13.5 \mathrm{~cm}$ long, $1.8-5 \mathrm{~cm}$ wide; leaf margins usually undulate; abaxial surface of leaf glabrous or nearly so

4: Leaves $1-7 \mathrm{~cm}$ long, $0.3-1.5 \mathrm{~cm}$ wide; leaf margins not undulate; abaxial surface of leaf densely hairy

5. Leaf margins not undulate or slightly undulate; inflorescence with c. 6 flowers; petals creamy-yellow, flushed maroon (especially in bud); fruit dark yellowishgreen when mature ......... P. bicolor $x$ P. undulatum

5: Leaf margins undulate; inflorescence with up to 35 flowers; petals cream; fruit bright orange when mature .3d. P. undulatum

\section{3a. Pittosporum eugenioides A. Cunn.,} Ann. Nat. Hist. ser. 1, 4: 106 (1840).

Common names: Lemonwood, Tarata (Maori).

Illustrations: Spencer (2002: 18); Salmon (1992: 132-133, fig. 1-10); pl. 3A.

Description: Trees to $5 \mathrm{~m}$ tall (to $12 \mathrm{~m}$ in New Zealand). Stems glabrous. Leaves alternate, petiole up to $20 \mathrm{~mm}$ long; lamina elliptic, 55-130 $\mathrm{mm}$ long, 22-45 mm wide, sub-coriaceous; adaxial surface glabrous, glossy; abaxial surface glabrous, paler than adaxial surface; margin not revolute, irregularly undulate (sometimes only slightly); apex acute to minutely apiculate; base cuneate. Flowers in many-flowered, terminal, compound umbels; sepals 1.5-2 $\mathrm{mm}$ long, glabrous apart from a few hairs on the margin, erect; petals up to $7 \mathrm{~mm}$ long, spreading, cream; ovary pubescent. Fruit a 2-valved capsule, up to $6.5 \mathrm{~mm}$ long, becoming glabrous or nearly so, black at maturity. Seeds c. $2.3 \mathrm{~mm}$ diam., deep burgundy, c. 5 per fruit, enclosed in a papery endocarp.

Discussion: Pittosporum eugenioides may be confused with the more commonly cultivated and naturalised $P$. undulatum, from which it differs by having a much greater number of flowers per inflorescence and much smaller fruits that are green at first and later mature to black (compared to orange in $P$. undulatum). The leaves of $P$. eugenioides have a prominent yellow midrib and when crushed have a strong lemon smell (Salmon 1992). Forms with variegated leaves are grown in gardens in Tasmania.

Distribution and habitat: Pittosporum engenioides is native to New Zealand where it is widespread in forest clearings, forest margins and along stream banks from sea level to $600 \mathrm{~m}$ (Salmon 1992). In Australia, it is naturalised in New South Wales, Victoria and Tasmania. In New South Wales, it is naturalised in the Upper Blue Mountains area in the Central Tablelands region where it is associated with disturbed dry sclerophyll forest (Hosking et al. 2007). In Tasmania, it has naturalised along forest margins, roadsides and the banks of watercourses in the East Coast and NorthWest regions (fig. 3).

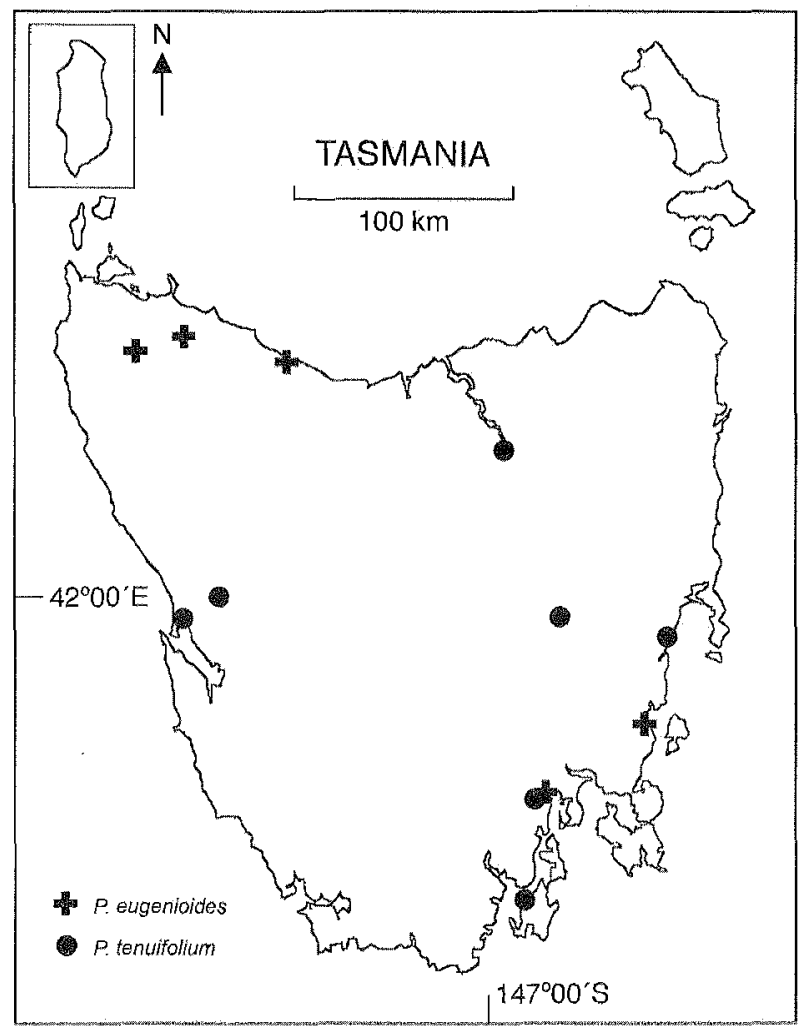

FIG, 3 - Geographical distribution of Pittosporum eugenioides and $\mathrm{P}$. tenuifolium as known from herbarium specimens. 

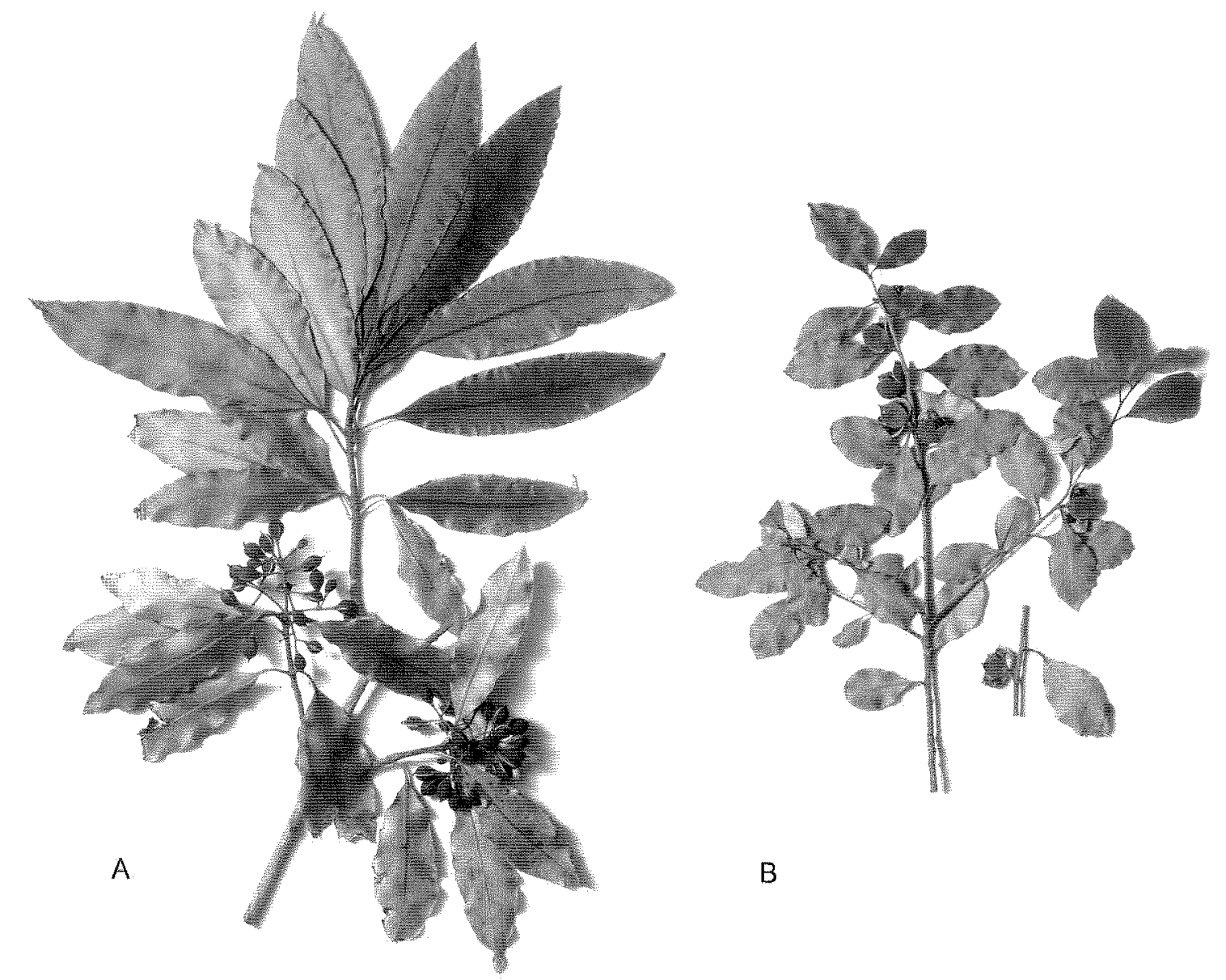

B

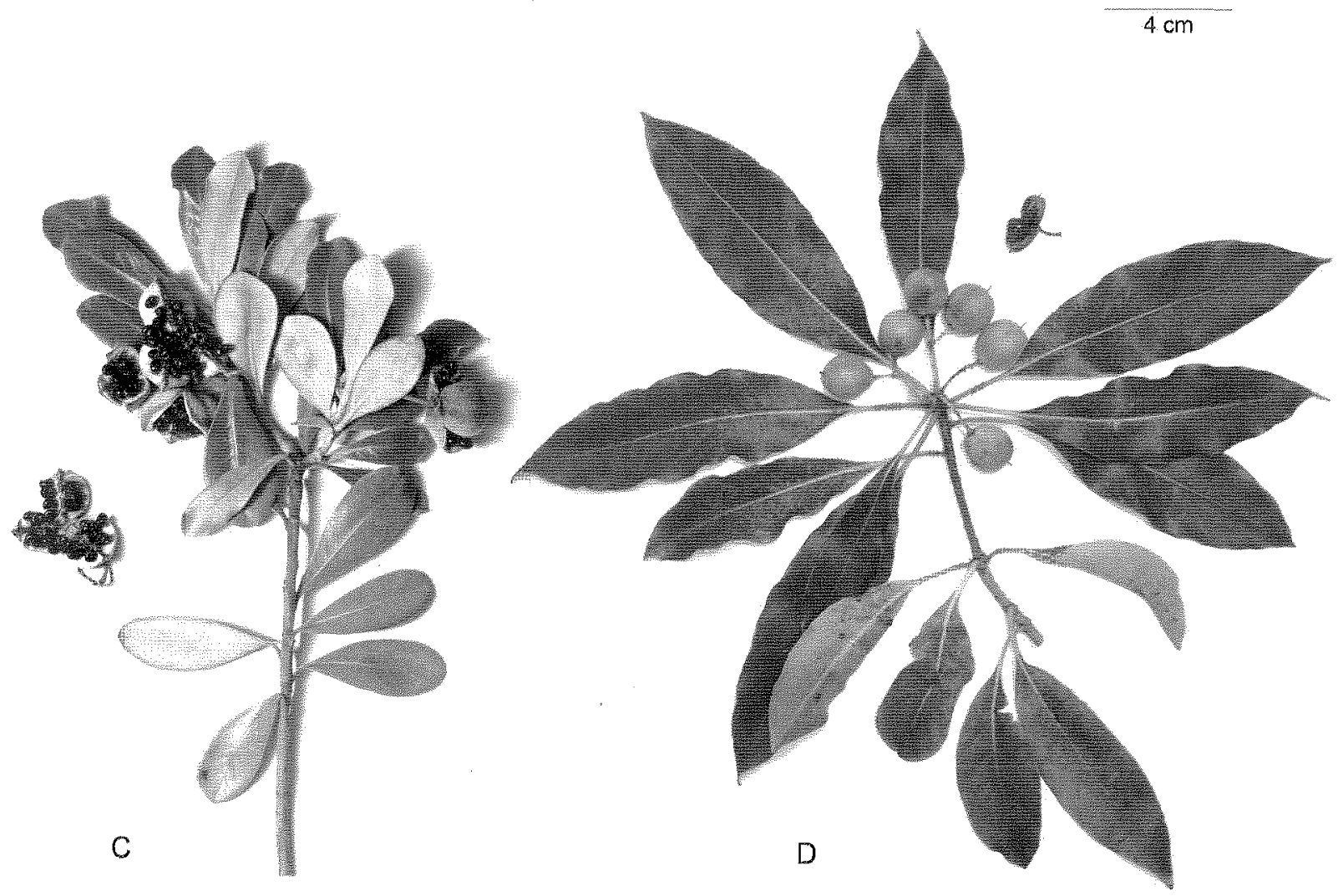

PLATE 3

Branches of (A) Pittosporum eugenioides, (B) P. tenuifolium, (C) P. crassifolium and (D) P. undulatum (all bearing mature fruit). 
First record: Jan. 1996, P.A. Collier

Selected specimens examined: TASMANIA: East Coast region: Medical Building, University of Tasmania, $29 \mathrm{Oct}$. 1999, A.M. Buchanan 15507 (HO); behind Spring Beach, Orford. T. Higgs' property, 13 Oct. 2002, G. Vaughan s.n. (HO). North-West region: Detention Falls, 12 Jan. 1986, P.A. Collier 1157 (HO); Millicent Road, Mawbanna, 15 Mar. 1995, A.M. Buchanan 13854 (HO); Burnie, Emu River, Emu. Heights, 31 Oct. 2003, M.L. Baker 242 (HO). NEW ZEALAND: Gorge Creek, East Talkaka, 16 May 1965, A.M. Buchanan s.n. (HO); Kawakawa Bay, South Auckland, Nov. 1966, E.N. Buchanan s.n. (HO).

\section{3b. Pittosporum tenuifolium Gaertn., Fruct. Sem. PI. 1: 286 (1788).}

\section{Common name: Black Matipo, Kohuhu (Maori).}

Illustrations: Richardson et al. (2006: 336); Phillips \& Rix (2002: 214-5); Spencer (2002: 19); Salmon (1992: 146-147, fig. 1-10); pl. 3B.

Description: Shrubs or trees to $6 \mathrm{~m}$ tall (to $8 \mathrm{~m}$ in New Zealand). Stems sparsely pubescent when young, becoming glabrous with age. Leaves alternate; petiole 7-12 mm long; lamina elliptic to obovate, $23-55 \mathrm{~mm}$ long, $10-25 \mathrm{~mm}$ wide, thinly coriaceous, with both surfaces at first sparsely pubescent, then becoming glabrous; abaxial surface paler than adaxial surface; margin not or only slightly revolute, variously undulate; apex acute to minutely apiculate, sometimes obliquely twisted; base cuneate. Flowers usually solitary in leaf axils (also in few-flowered cymes in New Zealand); sepals c. $3 \mathrm{~mm}$ long, hairy when young, erect; petals up to $10 \mathrm{~mm}$ long, recurved in the apical quarter, deep maroon; ovary pubescent. Fruit a 3-valved capsule, 8-10 mm long, dark brown to black at maturity: Seeds $c$. $3 \mathrm{~mm}$ diam., dark reddish brown to almost black, up to 6 per fruit (up to 16 in New Zealand material).

Discussion: Pittosporum tenuifolium can be readily identified by having solitary flowers and relatively small leaves (up to $55 \mathrm{~mm}$ long) that are botne on dark brown to black stems. Various forms are grown that differ in leaf colour and variegation; Spencer (2002) lists 29 cultivars. Naturalised plants in Tasmania mostly exhibit pale green leaves without variegation.

Distribution and habitat: Pittosporum tenuifolium is native to New Zealand where it grows on both the North and South Islands and is common in coastal to lower montane forest from sea level to $920 \mathrm{~m}$ (Allan 1961, Salmon 1992). In Australia, it is naturalised in New South Wales, Victoria and Tasmania and doubtfully naturalised in South Australia. In New South Wales, a small population has been recorded growing on the disturbed margin of shrubby woodland at Leura in the Central Tablelands region (Hosking et al. 2007). In Tasmania, it has been recorded throughout the state, mostly in shaded, moist habitats including the banks of watercourses and in wet Eucalyptus forest (fig. 3). A population of numerous plants ranging in size from 1 to $4 \mathrm{~m}$ tall was recently recorded growing in a forest at Lunawanna, Bruny Island.

First record: May 1984, A.M. Buchanan.

Selected specimens examined: TASMANIA: East Coast region: Tirzah, at entrance on main road, 26 May 1984, A.M. Buchanan 3587 (HO); Waterworks Reserve, 27 Jun. 2002, R. Glazik s.n. (HO). West Coast region: Queenstown, park section of Esplanade, Queen River, $100 \mathrm{~m} \mathrm{~S}$ of Penghana Road bridge, 16 Sep. 2004, M.L. Baker 662 \& A.M. Gray
(HO); Strahan, Hogarth Falls Peoples Park, 21 Nov. 2005, M.L. Baker 1665, A.M. Gray \&. K. Stewart (HO). Midlands region: Trevallyn, Cataract Gorge, track on N side of South Esk River between First Basin and Kings Bridge, 13 Feb. 2009, M.L. Baker 1972 \&. D. Lane (HO). South-West region: Lunawanna, Bruny Island, W of Bruny Island main road, 9 Sep. 2008, M.L. Baker 1903, K. Stewart \& E. Schrammeyer (HO). NEW ZEAIAND: Waitakere Range: Scenic Drive c. $1 \mathrm{~km} \mathrm{~N}$ of Piha Road, 4 Apr. 1974, A.E. Orchard 4153 (HO, AK); Balls Clearing Reserve, Puketitiri, Hawkes Bay, 15 Jun. 1984, A.M. Buchanan 3631 (HO).

3c. Pittosporum crassifolium Banks \& Sol. ex A. Cunn., Ann. Nat. Hist. ser. 1, 4: 106 (1840).

\section{Common name: Karo (Maori)}

Illustrations: Walsh \& Albrecht (1996: 536, fig. 110e); Spencer (2002: 18); Salmon (1992: 144-145, figs 1-9); pl. 3C.

Description: Shrubs or trees to $5 \mathrm{~m}$ tall (to $9 \mathrm{~m}$ in New Zealand). Stems grey tomentose when young, becoming glabrous with age. Leaves alternate; petiole 5-15 $\mathrm{mm}$ long; lamina spathulate to narrow-obovate, $30-85 \mathrm{~mm}$ long, 12-37 mm wide, coriaceous, adaxial surface pubescent, soon becoming glabrous; abaxial surface persistently grey tomentose; margin revolute, not undulate; apex sub-acute to rounded; base cuneate to attenuate. Inflorescence a terminal umbel with up to 5 flowers (up to 10 in New Zealand); sepals 3-6 mm long, pilose on abaxial surface, spreading to deflexed; petals up to $14 \mathrm{~mm}$ long, recurved in the apical third, deep maroon; ovary pubescent. Fruit a ( 2 or) 3-valved capsule, $15-25 \mathrm{~mm}$ long, tomentose, pale grey-green. Seeds c. $4 \mathrm{~mm}$ diam., black, numerous.

Discussion: Pittosporum crassifolium can be readily identified by its large, leathery leaves that have a persistent and dense covering of grey-coloured hairs on the abaxial surface. The fruits are the largest of all the taxa in Tasmania, being large globose capsules that open by three valves, and are initially covered with an indumentum of grey hairs that gives them a pale grey-green colour. A similar species, $P$. ralphii, also a New Zealand endemic, is naturalised in wet sclerophyll forest at Katoomba in the Central Tablelands region of New South Wales (Hosking et al. 2007). P. ralphii has leaves that are abruptly narrowed to the petiole and with flat to slightly downturned margins, and fruits that are $c$. $15 \mathrm{~mm}$ long. In contrast, $P$. crassifolium has attenuate leaf bases, revolute leaf margins and fruits up to $20 \mathrm{~mm}$ long (Allan 1961, Spencer 2002).

Distribution and habitat: Pittosporum crassifolium is native to the Kermadec Islands and the North Island of New Zealand, where it commonly occurs at forest margins and along the banks of watercourses (Allan 1961). It was introduced to Australia as a garden plant. It is regarded as doubtfully naturalised in South Australia and naturalised in New South Wales, Victoria, Norfolk Island and Tasmania. In New South Wales, it is naturalised on the Malabar Headland, Central Coast region (Conn 2011), whereas in Victoria, it has naturalised at a few coastal sites around Port Phillip Bay (Walsh \& Albrecht 1996). In Tasmania, it is naturalised on King Island where it is commonly found on sandy soils in remnant bushland surrounding the township of Currie. A small population of four plants has been recorded growing at Binalong Bay on the state's East Coast (fig. 4).

First record: Oct. 2005, K. Stewart. 


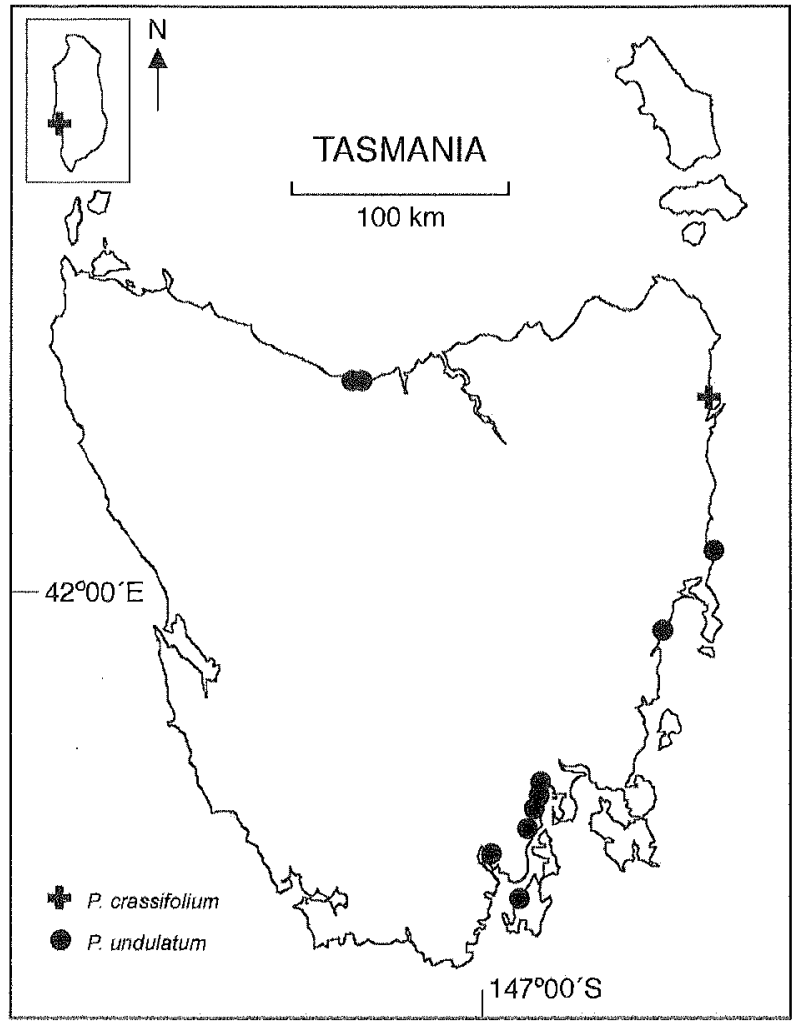

FIG. 4 - Geographical distribution of Pittosporum crassifolium and $\mathrm{P}$. undulatum as known from herbarium specimens.

Specimens examined: TASMANIA: King Island region: Camp Creek Reserve, Oct. 2005, K. Stewart s.n. (HO); King Island, Currie, old tip site behind Beach Road, 24 Feb. 2009, M.L. Baker 2010, M.F. Duretto, M. Batey \& G. Batey (HO); King Island, Currie, Beach Road, 26 Feb. 2009, M.L. Baker 2087, M.F. Duretto, M. Batey \& G. Batey (HO). North-East region: Binalong Bay foreshore, Mar. 2008, $R$. Skabo s.n. (HO). East Coast region: Rose Bay, Loatta Road, 24 Sep. 2009, M.L. Baker 2101 (HO). NEW ZEALAND: Ahuriri/Westshore old inner harbour, Napier, 26 May 1986, A.M. Buchanan 8563 (HO).

\section{3d. Pittosporum undulatum Vent., Descr. PI. Nouv. 8:76, t.76 (1802) (Pittosporaceae)}

\section{Common Name: Sweet Pittosporum.}

Illustrations: Richardson et al. (2006: 336); Walsh \& Albrecht (1996: 536, fig. 110g); Spencer (2002: 22); pl. 3D.

Description: Trees to $13 \mathrm{~m}$ tall. Stems glabrous. Leaves alternate, gathered in a whorl-like arrangement at the ends of stems; petiole up to $30 \mathrm{~mm}$ long; lamina elliptic to ovate, 60-135 mm long, 18-50 mm wide, sub-coriaceous, both surfaces glabrous, abaxial surface paler than adaxial surface; margin not to very slightly revolute, slightly to strongly undulate; apex acute, occasionally obliquely twisted; base attenuate. Flowers in a terminal umbel-like cyme with up to 35 flowers per cluster; sepals up to $10 \mathrm{~mm}$ long, sparsely hairy, erect; petals up to $16 \mathrm{~mm}$ long, recurved in the apical quarter, cream; ovary pubescent. Fruit a 2-valved capsule, up to $14 \mathrm{~mm}$ long, pubescent and green at first, becoming orange, and almost glabrous. Seeds $3-4 \mathrm{~mm}$ diam., orange to burgundy, numerous.
Discussion: Pittosporum undulatum can be readily identified by its fruits that ripen to a bright orange colour. A variegated cultivar ("Variegatum") is commonly cultivated. For notes on differentiating $P$. undulatum from the similar looking species, $P$. eugenioides, see under that species.

Hybrids between $P$. undulatum and $P$. bicolor have been recorded throughout the state and are not uncommon. Such plants were not known to be hybrids when they were first described as $P$. undulatum subsp. emmettii W.M. Curtis (Morris \& Curtis 1974). This hybrid also occurs in Victoria and New South Wales (Walsh \& Albrecht 1996).

The hybrid has the following characters that differ from the parents: young leaves with scattered hairs on both surfaces; margin flat to slightly undulate. Flowers in terminal clusters of c. 6. Petals creamy-yellow, flushed with crimson (especially in bud). Capsule dark yellowish-green when mature.

Distribution and babitat: Pittosporum undulatum is native to Queensland, New South Wales and Victoria. It has been widely planted as a garden ornamental and has subsequently spread from plantings and is naturalised in Western Australia, South Australia, New South Wales, Victoria and Tasmania. In New South Wales and Victoria, P. undulatum is native in rainforest and sclerophyll forests and woodland from coastal areas to the highlands (Walsh \& Albrecht 1996, Makinson 2002). Naturalised populations grow in wet forest and coastal scrub of southern Victoria and in forests in the Sydney region. In Tasmania, P. undulatum is the most common naturalised species of Pittosporum. It is a common environmental weed species that grows in a range of habitats but most commonly in coastal heath and dry forest bordering residential areas where it is also a common garden plant (fig. 4). It has also escaped from cultivation on Norfolk Island, Lord Howe Island (Green 1994), southern Africa, Mexico, the Caribbean, Azores, Hawaii (Weber 2003) and New Zealand (Heenan et al. 2002).

First record: Feb. 1974, E.B. Clayton. An undated, but most certainly earlier, specimen collected by $\mathbf{L}$. Rodway exists and, given its cited location (Botanical Gardens, Hobart), it is likely that it was taken from a cultivated specimen. Records held at the Tasmanian Herbarium indicate that L. Rodway collected in Tasmania from the mid-1870s to late 1930 s.

Selected specimens examined: TASMANIA: East Coast region: Bicheno, Lookout Reserve, 12 Feb. 1984, A. Moscal 6224 (HO, MEL); Tirzah Beach, $30 \mathrm{~m} \mathrm{~S}$ of mouth of Constable Gully Creek, 4 May 1984, D. Ziegeler s.n. (HO). SOUTH AUSTRALIA: Stirling. W side of Goulds Road, $c$. 0.22 miles [0.4 km] from its junction with Pomona Road, 20 Mar. 1957, Booth 54 (HO, NSW). NEW SOUTH WALES: c. 1 mile SE of Wolumla Princes Highway, Bega District, 17 Mar. 1964, R. Schodde 3486 (HO, NSW); Victoria Falls, Mt Victoria, 24 Mar. 1965, E.F. Constable 5721 (HO, NSW, MEL). VICTORIA: Blackburn, Blackburn Lake Sanctuary, 22 Sep. 1981, T.B. Muir 6635 (HO, MEL).

\section{ACKNOWLEDGEMENTS}

I would like to thank Gintaras Kantvilas for his significant support in the development of this manuscript. Thanks also to Miguel de Salas for his assistance in the preparation of the plates. Lyn Cave and Dalia Howe are to be thanked for their assistance in the production of the distribution maps and John Hosking and John Conran for their useful comments in their capacity as reviewers. 


\section{REFERENCES}

Allan, H.H. 1961: Flora of New Zealand, Volume 1. Government Printer, Wellington: $1085 \mathrm{pp}$.

Anon. 2007: Russell Lupin - Problem Weed: Fact Sheet. Department of Conservation: Te Papa Atawhai New Zealand. Available at: www.doc.govt.nz/upload/documents/...and.../wecds/ russcll_lupin_web.pdf

Baker, M.L. 2005: Contributions to a catalogue of alien plants in Tasmania I. Papers and Proceedings of the Royal Society of Tasmania 139: 33-48.

Baker, M.L. 2007: Contributions to a catalogue of alien plants in Tasmania II. Papers and Proceedings of the Royal Society of Tasmania 141(2): 187-196

Barker, B., Barker; R., Jessop, J. \& Vonow, H. (eds) 2005: Census of South Australian Vascular Plants Edition 5.00, Journal of the Adelaide Botanic Gardens, Supplement 1. Botanic Gardens of Adelaide and State Herbarium, Adelaide: $397 \mathrm{pp}$.

Buchanan, A.M. 2005: A Census of the Vascular Plants of Tasmania and Index to 'The Student's Flora of Tasmania', Fourth Edition, Tasmanian Herbarium Occasional Publication No. 7. Tasmanian Museum and Art Gallery, Hobart: 108 pp.

Cayzer, L.W., Crisp, M.D. \& Telford, I.R.H. 2000: Revision of Pittosporum (Pittosporaceae) in Australia. Australian Systematic Botany 13(6): 845-902.

Conn, B.J. 2011: New South Wales Flora Online (Pittosporum crassifolium), In PlantNET - The Plant Information Network System of The Royal Botanic Gardens and Domain Trust, Sydney, Australia. http://plantnet.rbgsyd. nsw.govalu.

Conran, J.G. \& Walsh, N.G. 1994: Agavaceac. In Walsh, N.G. \& Entwisle, T.J. (eds): Flora of Victoria, Volume 2, Ferns and Allied Plants, Conifers and Monocotyledons. Inkata Press, Melbourne, Victoria: 718-720.

Conran, J.G. 1998: Lomandraceae. In Kubitzki, K. (ed.): The Families and Genera of Vascular Plants, Volume 3, Flowering Plants, Monocotyledons, Lilianae (except Orchidaceae). Springer-Verlag, Berlin: 354-365.

Cooper, R.P. 1959. Birds feeding on Pittosporum seeds. Emu 59: $60-1$.

Duretto, M.F. 2009: Introduction, version 2009:1. In Duretto, M.F. (ed.): Flora of Tasmania Online. 7 pp. Tasmanian Herbarium, Tasmanian Museum \& Art Gallery: Hobart. ISBN 978-1-921599-45-3 (PDF); www.tmag.tas.gov.au/ floratasmania.

Gardner, C. \& Murray, L. 2002: Lupinus, In Harden, G.J. (ed.) Flora of New South Wales, Volume 2, Revised Edition. New South Wales University Press, Sydney: 503-505.

Green, P.S. 1994: Pittosporaceae, In Orchard, A.E. (ed.): Flord of Australia Volume 49, Oceanic Islands 1, Australian Government Publishing Service, Canberra: 156-158.

Heenan, P.B., de Lange, P.J., Cameron, E.K. \& Champion, P.D. 2002: Checklist of dicotyledons, gymnosperms, and pteridophytes naturalised or casual in New Zealand: additional records 1999-2000. New Zealand Journal of Botany 40(2): 155-174.

Holmgren, P.K., Holmgren, N.H., \& Barnett, L. 1990: Index Herbariorum. Part 1. The Herbaria of the World. Eighth Edition. New York Botanical Garden, New York: 693 pp.

Hosking, J.R., Conn, B.J., Lepschi, B.J. \& Barker, C.H. 2007 : Plant species first recognised as naturalised for New South Wales in 2002 and 2003, with additional comments on species recognised as naturalised in 2000-2001. Cunninghamia 10(1): 139-166.

Huxley, A. 1999: The New Royal Horticultural Society Dictionary of Gardening, Macmillan, London (4 volumes).

Knox, J., Campbell, S., Field, B., Thompson, R. \& Hall, E. 2006: Species for Profit: A Guide for Tasmanian Pastures and Field Crops. Department of Primary Industries, Water and Environment. Hobart: 108 pp.

Mabberley, D.J. 2008: Mabberley's Plant-Book; A Portable Dictionary of Plants, their Classiffation and Uses, Third Edition. Cambridge University Press, Cambridge: 1021 pp.

Makinson, R.O. 2002: Pittosporaceae, In Harden, G.J. (ed.) Flora of New South Wales, Volume 3. University of New South Wales Press, Sydney: 65-74.

Moore, L.B. \& Edgar, E. 1970: Flora of New Zealand, Volume 2, Indigenous Tracheophyta: Monocotyledons Except Gramineae. Government Printer, Wellington: 354 pp.

Morris, D.I. \& Curtis, W.M. 1974: Recent additions to the Tasmanian Flora and some notes on nomenclature. Records of the Queen Victoria Museum 50: 1-5.

Orchard, A.E. 1988: A natural regions map for Tasmania. Papers and Proceedings of the Royal Society of Tasmania 122: 47-51.

Philips, R. \& Rix, M. 2002: The Botanical Garden, Volume 1, Trees and Shrubs. Macmillan, London: $491 \mathrm{pp}$.

Richardson, F.J., Richardson, R.G. \& Shepherd, R.C.H. 2006 Weeds of the South-East: An Identification Guide for Australia. R.G. Richardson and F.J. Richardson, Meredith: 438 pp.

Salmon, J.T. 1992: The Native Trees of New Zealand. Reed, Auckland: $384 \mathrm{pp}$.

Simpson, P. 2000: Dancing Leaves: The Story of New Zealand's Cabbage Tree, Ti Kouka. Canterbury University Press, Christchurch: 324 pp.

Spencer, R. 2002: Horticultural Flora of South-Eastern Australia Volume 3: Flowering Plants, Dicotyledons, Part 2. University of New South Wales Press, Sydney: 619 pp.

Spencer, R. 2005: Horticultural Flora of South-Eastern Australia, Volume 5: Flowering Plants, Monocotyledons. University of New South Wales Press, Sydney: 638 pp.

Stace, C.A. 2010: New Flora of the British Isles, Third Edition. Cambridge University Press, Cambridge: $1232 \mathrm{pp}$.

The Royal Botanic Gardens and Domain Trust (7 Oct. 2011). PlantNET - The Plant Information Network System of The Royal Botanic Gardens and Domain Trust, Sydney, Australia http://plantnet.rbgsyd.nsw.gov.au

Walsh, N.G. \& Albrecht, D.E. 1996: Pittosporaceae. In Walsh, N.G. \& Entwisle, T.J. (eds): Flora of Victoria, Volume 3, Dicotyledons, Winteraceae to Myrtaceae. Inkata Press, Melbourne: 526-539.

Walsh, N.G. \& Stajsic, V. 2007: A Census of the Vascular Plants of Victoria, Eighth Edition. Royal Botanic Gardens Melbourne, South Yarra: $307 \mathrm{pp}$.

Webb, C.J. 1988: Fabaceae. In Webb, C.J., Sykes, W.R. \& Garnock-Jones, P.J. (eds): Flora of New Zealand, Volume IV, Naturalised Pteridophytes, Gymnosperms, Dicotyledons. DSIR, Botany Division, Christchurch: 635-710.

Weber, E. 2003: Invasive Plant Species of the World: A Reference Guide to Environmental Weeds. CABI Publishing, Oxon: 548 pp.

Wilson, K.L. 2011: New South Wales Flora Online (Cordyline australis), In PlantNET - The Plant Information Network System of The Royal Botanic Gardens and Domain Trust, Sydney, Australia. http://plantnet.rbgsyd.nsw.gov.au.

(accepted 1 November 2011) 